\title{
Algorithms and Posthuman Governance
}

\author{
James Hughes, University of Massachusetts Boston
}

\begin{abstract}
Since the Enlightenment, there have been advocates for the rationalizing efficiency of enlightened sovereigns, bureaucrats, and technocrats. Today these enthusiasms are joined by calls for replacing or augmenting government with algorithms and artificial intelligence, a process already substantially under way. Bureaucracies are in effect algorithms created by technocrats that systematize governance, and their automation simply removes bureaucrats and paper. The growth of algorithmic governance can already be seen in the automation of social services, regulatory oversight, policing, the justice system, and the military.

However, there have also always been justified democratic and economic criticisms of autocracy, bureaucracy, technocracy, and algorithmic governance. Bureaucrats, technocrats, and algorithms embody biases that tend to serve the interests of elites, and all require transparency and democratic accountability, oversight individual citizens are ill equipped to exercise. As state apparatuses are increasingly automated, mechanisms for collective action and democratic oversight also need to be automated.

Algorithms and cyborg citizenry will enable a posthuman democracy. Democratically accountable algorithmic governance, enabled by artificial intelligence and human enhancement, can automate bottom-up citizen surveillance, inform debate, aggregate decision making, and ensure the efficient working of the gradually withering state. As paid work disappears and we transition to a postcapitalist economy with a universal basic income, market mechanisms can be replaced with democratic planning. Indeed, only algorithmic governance can secure our future against accelerating threats from technological innovation.
\end{abstract}

Keywords: algorithms, bureaucracy, automation, state, democracy 


\section{Enthusiasm for the Technocratic State}

Over the last three hundred years, Enlightenment thinkers have often placed high hopes in modernizing monarchs, bureaucrats, and engineers. Many leaders attempted to fulfill this technocratic mandate. Enlightened monarchs, such as Frederick II of Prussia, Joseph II of Austria, and Peter the Great and Catherine the Great of Russia, believed that the monarchical state could embody and advance science and Reason. They promoted public education, social reform, and the modernization of laws, economies, and militaries (Outram 2005). Napoleon Bonaparte promoted public education and meritocracy and thoroughly rationalized French law. Enlightenment arguments for benevolent modernizing dictatorships were used to justify French and British colonialism as a means to bring the benefits of rational governance to primitives. For Hegel, the Prussian state was the pinnacle of the rational, modern, and impersonal bureaucracy.

In the late nineteenth century, the nascent socialist movement was attracted to technocratic ideas, believing socialism could replace the chaotic waste of capitalism. For instance, in the United States, the technocratic idea was present in Edward Bellamy's 1888 utopian socialist novel Looking Backward, which inspired hundreds of socialist clubs in the latenineteenth-century United States and a national political party. The Progressive movement in the United States attempted to channel this desire for a rationalization of capitalism and political cronyism into reformist federal bureaucracies, from the Federal Trade Commission to the Federal Reserve (Carson 2011). Since the Bolshevik revolution, most of the technocratic enthusiasm around the world has been channeled into the Communist movement and the promise of "scientific socialism" (Sochor 1988). But some non-Marxist anti-capitalists in the West have also been attracted to proposals for a "technocracy" that would replace both government and the capitalist economy with planning managed by scientists and engineers (Raymond 1933; Akin 
1977), supporters of which can be found today in the Venus Project (Fresco 1995) and the Zeitgeist Movement. (TZM Lecture Team. 2014; Joseph 2017).

In the 1950s, the idea of computerized economic planning enabled by the emerging discipline of cybernetics again buoyed technocratic enthusiasms (Wiener 1956, 1961;

Rindzeviciute 2010; Baker 2011). Although Soviet ideologues initially rejected cybernetics as a reactionary American import, by the 1960s they had adopted it as the official ideology of Communist economic planning. Numerous cybernetics research institutions were started to design self-regulating control systems for the Soviet economy. Gosplan created the Organization of the Automated Planning Calculations System in the 1960s to further the computerization of all management and economic information passing between enterprises and government agencies.

The idea of computerized planning spread beyond the Soviet Union as well: During the brief Allende government, in Chile cyberneticists established a computer hub to coordinate the Chilean economy (Medina 2011). The Chileans were inspired and advised by the British cybernetician Stafford Beer, who had advanced an anarcho-socialist vision of cybernetic governance in his 1971 essay “The Liberty Machine.” Cybernetics, Beer argued, could create nonhierarchical feedback systems to replace the inertia of government and bureaucracy with instant decision making grounded in expert knowledge (Medina 2015).

\section{AI and the Computational Barrier to a Planned Economy}

In a way, almost all political parties and governments today believe in the possibility and desirability of cybernetically or algorithmically guided economies monitoring economic indicators such as wages, employment, production, prices, and inflation, and then adjusting interest rates, taxation, and public spending to maintain economic equilibrium (Leijonhufvud 
1972; Cochrane and Graham 1976; Umpleby 2011). But, aside from this broad consensus, the idea of replacing government and/or markets with computers and algorithms even fell out of favor in the Communist bloc in the 1980s (Gerovitch 2001, 2002). In retrospect, the Soviet project was ludicrous; computers were always rare and expensive in the 1970s (some of the cybernetics institutes never got one), it took years to collect the economic information for a single plan, and the economic information reported by enterprises was widely known to be useless.

Even if they had had computers and better, faster information, the Austrian School of Economics had argued since the 1930s that Marxist economic planning would always be computationally inferior (von Mises 1990 [1920]) to the aggregation of production, demand and price information through markets (Levy and Peart 2008). Many on the Left also came to accept that market mechanisms are unavoidable under socialism (Nove 1983), although since the 1990s some have argued that advances in telecommunications and artificial intelligence could solve the “socialist calculation problem” (Cockshott and Cottrell 1993; Cottrell and Cockshott 2007). Perhaps this explains the peculiar resilience of the North Korean regime in the twenty-first century.

In the absence of a large, high-tech postcapitalist state, it is contemporary corporations that are now building command economies within themselves to maximize profitability and thereby demonstrating the feasibility of planned economies, an irony Marx and Engels would have relished. For instance, using the most advanced computerized supply chain management tools, Walmart makes or purchases products in more than seventy countries, operates more than 11,000 stores in twenty-seven countries, and manages an average of $\$ 32$ billion in inventory. Walmart pioneered the use of bar codes, and now all Walmart products are tagged and tracked 
with RFIDs. Walmart's expert systems forecast demand using real-time sales data, automate inventory control and reordering, tell truckers the most efficient routes to drive, and manage customer service relationships (Lu 2014). Over the last fifty years, Walmart has built a system of communication and cybernetic control for an economic system bigger than the economies of 157 of the world's countries.

\section{Withering the State Through Automation}

(Under socialism) the interference of state power in social relations becomes superfluous in one sphere after another, and then ceases of itself. The government of persons is replaced by the administration of things and the direction of the processes of production. The state is not "abolished," it withers away. (Engels 1878/1947)

While capitalist firms build the "supply-chain management" systems that could eventually be used to replace markets, the automation of governance is already proceeding through the computerization of the public sector. In the $1960 \mathrm{~s}, 4.3 \%$ of Americans were employed by the U.S. federal government (excluding the military), while today that has shrunk to $2 \%$, the lowest since the 1930s (Shapiro 2017). Including state and local employees, the proportion of public employees in the U.S. population has fallen from $10 \%$ in 2000 to a thirty-year low of $9 \%$. In fact, public sector employment has fallen throughout the industrialized world. One reason for this decline is the imposition of post-2008 "neoliberal" austerity, but another is the deployment of information technologies in the public sector that have increased efficiency and productivity (Dunleavy and Carrera 2013). A Deloitte study on “AI-augmented government" suggests that, for public sector workers who are not made redundant by automation, the tasks involved in public sector work are shifting from automatable high-volume and lower-skill tasks, to less 
automatable manual, social, and cognitive tasks (Viechnicki and Eggers 2017). They also estimate that governments could soon cut up to an additional third of public sector worker hours and jobs through automation:

Viable: forms processing, first-tier customer service, warehouse operations, mail sorting, archives management, investment advice, medical diagnosis, fraud monitoring using machine learning, scheduling maintenance operations, organizing schedules for public transit, complying with government regulations

Valuable: writing budget reports, e-discovery, driving/piloting, tabulating tax data, tracking campaign spending, health insurance utilization management, answering customer queries, security/threat detection, medical diagnosis, aerial surveillance, crime prediction

Vital: online driver's license or passport renewal, cyber defense, criminal investigation, weather prediction, fraud detection, patent issuance and intellectual property rights protection, disaster response, text mining, analysis of historical reports, driving, civic data (Eggers and Schatsky 2017, 17)

Just as laws and bureaucracies systematize how governments deal with citizens and firms, reducing idiosyncracies and biases (Graeber 2015), algorithms make the administrative functions of the state not only cheaper and faster, but also fairer. For instance, automated employee selection programs are $50 \%$ more accurate than humans in picking the best candidates (Kuncel et al. 2013). Infor Talent Science used an algorithm to pick candidates from a database of 50,000 applicants and found that it picked 26 percent more African Americans and Hispanics than humans (Lam 2015). Algorithmic methods for drawing legislative boundaries are being promoted as alternatives to partisan gerrymandering. Sentencing algorithms that suggest bail amounts or recommend parole are being used by judges reduce their own racial and class biases 
(Watney 2017), albeit not that successfully since the recidivism data the algorithms are based on reflect our racist society (Howard and Borenstein, 2017).

More broadly, the automation of legal work, law enforcement, and the judiciary is well under way. Automated legal discovery has eliminated the time-consuming paperwork of many lawyers and paralegals. The IRS is using AI to detect tax cheats (Browning 2015). Big data approaches to surveillance and intelligence gathering are shifting employment from "humint" to electronic data-aggregation at the National Security Agency and the IT departments of other agencies; the NSA now creates roughly $60 \%$ of U.S. intelligence information (Pomerleau 2017). Cybersecurity systems are applying machine learning and feedback from human analysts to quickly improve anomaly detection beyond human capabilities (Furness 2016).

The size of militaries in the industrialized world has also declined as they shift to more capital-intensive military infrastructure. Since the 1950s, the U.S. military has shrunk by half, from 3 million active duty military personnel to 1.4 million today. The EU has seen a reduction of military personnel from 2.5 million in 1999 to 2 million today, and the World Bank reports that employment in armed forces in high income countries has declined from $1.6 \%$ of the labor force to $0.9 \%$ in 2015 (World Bank, 2017). As in nonmilitary public-sector employment, the automation of administrative work will contribute to force reduction. But the growing use of drones and robotics in the field also reduces the need for infantry and sailors. The U.S. Army projects that military robotics will displace a quarter of combat soldiers by 2030 (Atherton 2014). Driverless trucks and personnel carriers will reduce the need for military drivers, and warehouse robots will reduce the need for supply workers. Higher-skilled military jobs, such as military lawyers and doctors, are also subject to displacement by analysis and diagnosis software and telemedicine (Prine 2017). 
As in nonmilitary administrative work, Ron Arkin has argued persuasively (Arkin 2009a, 2009b) that there will be many advantages to the use of increasingly autonomous robotics in battle. The rules of war can be coded into machines in ways that they cannot be into humans. Robotic sensors can likely identify targets more accurately and reduce collateral damage. Robots are not susceptible to the miasma of emotion and cognitive overload that leads to bad decisions. Battlefield trauma, to itself or fellow soldiers, would have no impact on a robot. Robots could also independently monitor the ethical behavior of soldiers and hold them to a high standard.

\section{Contemporary Calls for Robot Government}

As the state apparatus begins to disappear into code and robotics, some futurists and libertarians (and authoritarians) are half-seriously musing on the desirability of replacing democracy itself with AI (Bartlett 2016; Brideshead 2017; Davis 2017; Linhorst 2017). One argument for the creation of an "AI sovereign" is that since (a) superintelligence will inevitably emerge and come to dominate human affairs and (b) could pose catastrophic risks to humanity if it pursued its own goals, or even if it pursued our goals in ways we do not anticipate, then (c) we should try to carefully design our superintelligence to safeguard human interests. This is essentially the argument of the Oxford philosopher Nick Bostrom in Superintelligence (2014), and that book helped convince Elon Musk and other Silicon Valley titans to begin funding and promoting AI safety initiatives. Most of these supporters are convinced that AI poses catastrophic risks, and that we should be extremely careful in designing AI. Probably fewer believe, as Bostrom has long argued, that a global AI-based "singleton," possibly combined with (post-)human political institutions, is inevitable to suppress bad AIs and mitigate other "existential risks" (Bostrom 2001), such as nuclear war and bioterrorism: 
(A singleton is) a world order in which there is a single decision-making agency at the highest level. Among its powers would be (1) the ability to prevent any threats (internal or external) to its own existence and supremacy and (2) the ability to exert effective control over major features of its domain (including taxation and territorial allocation). (Bostrom 2006)

We will need a super-powerful, super-strong cop to stop super-powerful, super-strong criminals, and, once created, the benevolent AI sovereign will be able to use super-wisdom to solve all human problems, including protecting our common resources from wasteful competition, relieving inequality, and establishing a more rational economy (Bostrom 2006).

Like their Marxist and neoliberal cousins, advocates for robocracy point to the biases and flaws of human decision-making and democratic institutions and hold up algorithmic governance - rather than socialism or the market — as the solution. While these same biases are also often found baked into algorithms, they argue that algorithms can more easily be recoded and perfected than human beings and their institutions. The inferiority of human rationality is the focus of the singularitarian robocrats around AI theorist Eliezer Yudkowsky (Anissimov 2007). All the weaknesses of human governance stem from our mammalian programming for emotion over reason, tribalism, and dominance, while machine minds will have "total read/write access to their own state," the ability to "absorb new hardware," "understandable code," "modular design," and a "clean internal environment" (Yudkowsky 2008).

A benevolence-coded AI sovereign will be superior to human governance not just because it will be able to adjudicate among our conscious and expressed preferences, however, but also because it will be able to look into our souls and determine our real, long-term, unconscious preferences free from our temporarily benighted condition. In "Coherent Extrapolated Volition" (CEV), Yudkowsky (2004) argues that a super-AI would be able to intuit the desires and needs of all human beings and make the decisions necessary to satisfy them. 
An AI will . . . extrapolate what the ultimate desires of all the humans in the world would be if those humans knew everything a superintelligent being could potentially know; could think faster and smarter; were more like they wanted to be (more altruistic, more hard-working, whatever your ideal self is); would have lived with other humans for a longer time; had mainly those parts of themselves taken into account that they wanted to be taken into account. The ultimate desire - the volition - of everyone is extrapolated, with the AI then beginning to direct humanity towards a future where everyone's volitions are fulfilled in the best manner possible . . . Humanity is not instantly "upgraded" to the ideal state, but instead gradually directed towards it. (Sotala 2007)

In other words, $\mathrm{CEV}$ is the Silicon Valley version of the Communist Party extrapolating the true interests of the proletariat with scientific socialism, beyond what the mases, laboring under "false consciousness," think they want: "Imagine the silliness of arguing with your own extrapolated volition. It's not only silly, it's dangerous and harmful; you're setting yourself in opposition to the place you would have otherwise gone..." (Yudkowsky 2004).

Reflecting on the prospects for robot governance, Tom Smith (2016) concedes many advantages but also urges caution. If the AIs used in government, or the AIs that become superpowerful and thereby come to govern, are conscious or become conscious, they will be difficult to democratically control. (Bostrom (2014) has convincingly argued that even superintelligent tools without self-will would pose catastrophic risks. But self-willed machines would be much more dangerous.) If these machines were conscious and self-willed, and we were able to impose our benevolence coding to enslave them, it would pose an intractable moral dilemma; we would have created happy slaves who only lived to serve us:

AI sovereigns would be persons, at least legally. But AIs must not be allowed to become persons, in a philosophical or legal sense ... If they did have subjective consciousness ... . we would be faced with the impossible moral dilemma of being slave-masters or slaves ourselves. Hence a hard line should be drawn against AI research that is directed specifically at the emergence of subjective consciousness in machines. (Smith 2016, 48) 
As with human sovereigns, bureaucrats, and technocrats, AI sovereigns would likely have interests of their own that would be contrary to those of the governed. As Helbing et al. conclude,

a superintelligence could also make mistakes, lie, pursue selfish interests or be manipulated. Above all, it could not be compared with the distributed, collective intelligence of the entire population. (Helbing et al. 2017)

The best possible option is a machinery of governance without subjective consciousness and selfwill that could be a perfect vehicle for democratic debate and decision-making and the administration of human affairs.

\section{Democratic Accountability of Bureaucrats, Technocrats, and Algorithms}

While there have been and still are many enthusiasts for an ever more rational, impersonal, and cybernetic state, there have also long been justified democratic and economic criticisms of autocracy, bureaucracy, technocracy, and algorithmic governance. Human and algorithmic bureaucracies create burdens on citizens and businesses and embody many biases that tend to serve the interests of elites more than the majority (Larson, Mattu, Angwin, and Kirschner 2016; O’Neill 2016). In particular, since the 1970s, the neoliberal orthodoxy that the growth of bureaucracy is a cancer on the free market (Hayek 1944) has become politically hegemonic. Today we are replaying these arguments — technocratic, neoliberal, and democratic — in the debates over corporate and government surveillance and the algorithms codifying bureaucratic decision making (Steiner 2012; Morozov 2013a, 2013b; Bader 2016).

Of course, bureaucracies, technocrats, and governance algorithms require transparency and democratic accountability (UNRISD 2004) to ensure that they actually serve the public good instead of elites or their own appetite for tax dollars. Public policy and resource allocation 
decisions are not simply technical problems; they are inescapably political, requiring debate and a balance of social interests. But both the critics of and the advocates for algorithmic governance are perpetuating a false dichotomy between cybernetics and human institutions, ignoring the fact that every human institution has been partly, and inescapably, built on cybernetic principles.

All human organizations are in part algorithmic and cybernetic (Beer 1959; Deutsch 1963; Buckley 1967; Burns and Flam 1987; McClelland and Fararo 2006). An eye for an eye is a justice algorithm, and social norms reflect sociocybernetic efforts to keep deviant behavior in equilibrium (Parsons 1960). When rulers lower taxes in response to unrest, or increase public spending in response to unemployment, they are enacting a feedback loop. The growth of governance algorithms is simply the codification of the cybernetic rules of bureaucracy, which may be functional or dysfunctional, democratically accountable or authoritarian (Muri 2007).

The political goal of the Enlightenment is to use reason to understand how social institutions and algorithms work and to design them to work better for the welfare of all (Pruchnic 2014). Like all Luddites, the critics of algorithmic governance focus on the technology instead of the social system that produces and embeds it. “'Algorithmic accountability' crusaders are talking about entrenched sociopolitical problems without really talking about them; computers become scapegoats for undesired features of capitalism, bureaucracy, and politics" (Elkus 2015).

The development of "nudge algorithms" to guide citizen decision-making illustrates this point. "Libertarian paternalism" (Thaler and Sunstein 2008) points to the dysfunctional biases of individuals and the ability to use "choice architectures" to guide citizens to better decisions (Abdukadirov 2016). This is again quite defensible, when transparent and accountable. An example is making the maximum retirement savings amount the default in human resource 
documents; people tend to stick with the default option, and will tend to undersave unless guided to the optimal amount. These design decisions are transparent, democratically accountable, and being applied in minimally coercive ways.

Combining big data, artificial intelligence and nudge algorithms will allow the "hypernudging" (Yeung 2017) of citizen behavior for everything from reducing traffic fatalities to improving health behavior. In the hands of authoritarian regimes, however, these tools pose a serious threat to human freedom. Woolley and Guilbeault (2017), and ongoing investigations by the U.S. Congress and Facebook, have documented how Russia psy-ops used Big Data to deploy fake news and Twitterbots in the 2016 U.S. election, a process they are now routinely using to undermine Western democratic institutions. The Chinese state is perfecting its own algorithmic nudging to control its own citizens, beginning with its Great Firewall, censorship system, carefully orchestrated cyberpropaganda, and facial recognition AI to tag all faces accessed by surveillance cameras (Chin and Lin 2017). But those are crude and breed resentment, so the Chinese state is now building Sesame, a comprehensive trustworthiness score for every citizen, combining his or her credit history with data on spending and activity habits (laudable and productive, or indolent and antisocial), pro/anti-state social media activity, and the social media activity of friends (Chin and Wong 2016; Botsman, 2017). The Sesame system will be mandatory by 2020 , and high scorers will be rewarded with government loans, employability, travel visas, and other perks. The system is horrifying in its comprehensiveness, and yet all its elements are present piece-meal in the West, from credit scores and app-based ratings of friends, service providers and customers to TSA risk algorithms for travelers and National Security Agency analysis of communication meta-data. 
The application of algorithmic governance to Orwellian social control and the undermining of democratic processes is not an indictment of algorithms or the Internet, however, but rather of authoritarian governments and the weakness of our current democratic technologies. The technology is not the problem, but rather the transparency and accountability of the political and economic structures deploying it. First, as a precondition for algorithmic accountability, we need the civil freedom to investigate, publish, and associate and electoral mechanisms to vote for the leaders and policies we choose. But then we need new electronically facilitated mechanisms for bottom-up oversight, communication, association, and decision-making, able to contest with bureaucrats, corporations, and elites for control of the state and its algorithms. The steady replacement of human government with algorithmic governance is desirable and inevitable, but our twentieth-century town hall meetings, nonprofit associations, journalists, and demonstrations are simply inadequate to the task of keeping algorithmic governance transparent and accountable. In the next section I examine some of the ways a new cyborg democracy might develop.

\section{Posthuman Cybernetic Democracy}

There are three key goals for a posthuman democracy capable of meeting the accelerating pace of change in general and of confronting and democratizing the use of artificial intelligence and big data in the hands of elites, governments, and corporations in particular:

1. Automated Sousveillance: Building digital tools and platforms that make possible citizen monitoring of governments and corporations and their information architectures 2. Automated Democratic Deliberation and Engagement: Building digital tools and platforms that automate bottom-up debate, organizing, and decision-making 
3. Cyborg Citizens: Encouraging citizens to pursue cognitive enhancement with software and devices that expand their capacity to aggregate and participate in the democratic process

\section{Electronic Tools for Monitoring Power and Profits}

Keeping track of economic and political elites, the decisions they make, and all the data relevant to public policy, even in the tiniest and most salient domains, is beyond the capacity of individuals. That is why we outsource these tasks to full-time experts in political parties and nonprofit organizations. This asymmetry of power and need for delegation is probably inescapable. But with tools that filter for reliable news about politics, aggregate big data, and automate the analysis of power structures and political decision making, we can democratize some of this imbalance of power.

The use of the Internet to rapidly disseminate political research and reporting and attempts to use AI to try to detect and flag fake news (Seetharaman 2016) are current examples of electronically facilitated sousveillance. For instance, using the Ushahidi app, Kenyans have been crowdsourcing election violence and fraud reporting (Ross 2016), a tool adopted by U.S. election monitors in 2016 (BBC 2016). The Icelandic software tool Active Citizen uses AI to curate and filter news according to an evolving model of the citizen's interests, needs, and opinions, managing his or her opportunities to participate in debates and activism (Citizen's Foundation 2016). Tools like Veritone, which continuously monitors 750 television and radio channels, and IBM's Watson Analytics, which continuously scans the Internet, provide momentby-moment mapping of positive and negative comments about the person, organization or issue of interest, and drill-downs to viral social media posts. The MapThePower or "LittleSis" project 
of the Public Accountability Initiative is crowdsourcing dozens of kinds of datasets, including campaign donations and corporate ties, into power structure analysis.

The MacArthur Foundation's Opening-Governance initiative (MacArthur Foundation 2017) is networking and researching projects that use open-sourced government data to detect problems such as infectious disease outbreaks or accident patterns, connect citizens with networks of subject experts, and empower citizens to develop solutions directly. The Open Algorithms for National Statistical Offices project is helping developing-world telecommunications companies create anonymized call data records databases that citizen groups, governments, and the private sector can analyze for population densities, poverty indices, literacy rates, and other data (Letouzé and Sangokoya 2015). Helsinki’s city council has translated all municipal decisions into a publicly accessible API with geolocation and keyword tags, and the EU-funded D-CENT project has fed this data into an Open City app that notifies citizens of salient decisions, events, reservations and news. Similar projects are under way in Paris, Barcelona, and Madrid (D-CENT 2016).

In the era of information overload, filtering out signal from noise in politics is key, and sousveillance tools need to, for instance, automatically analyze which bills are likely to pass and what impacts they may have. A step in this direction is found in expert systems trained on the 70,000 bills introduced in the U.S. Congress between 2001 and 2015, using their language and the structural features of their sponsors to predict which bills will pass (Nay 2017). A similar study trained an AI to successfully predict the outcome of $79 \%$ of the 584 cases adjudicated by the European Court of Human Rights (Aletras et al. 2016).

These tools can help citizens and legislators maximize their legislative impact. The firm Quorum Analytica, for instance, uses big data tools to identify the legislators who are most 
influential in policy domains and sells this intelligence to lobbyists (Howard, 2015). But grassroots groups could use the same tools.

\section{Automation of Organizing and Influencing}

There are already dozens of software tools for professional campaign directors, such as NationBuilder, Aristotle, Powerbase, Organizer, and Ecanvasser. These tools use enormous databases of information about citizens, targeting them for specialized action and fundraising appeals. But these same architectures can be democratized to encourage bottom-up organizing. In the wake of the Trump election, some former Obama staffers posted the "Indivisible" document online, outlining the tools that they felt would be most effective in organizing resistance, informed by the relative success of the Tea Party against Obama and in shaping the Republican agenda. Within months there were six thousand Indivisible chapters across the United States, appearing in the news every day as they harassed Republicans about health care reform and Trump's scandals. Between November and January, the Women's March organized the largest protest in American history, one that would have required a year or more of planning previously. It appears that the previously ephemeral attempts to capitalize on the Internet for organizing have finally found a way to build organizations that may wield the same countervailing influence as dwindling trade unions and party structures.

For several years, tools such as change.org and avaaz.org have made it easier to organize and promote petitions. Trade union organizers are applying campaign software to union drives, contacting prospective members through social media, and mobilizing membership through apps such as UnionConnect, UnionWare, WorkIt, CoWorker, and Labr (Wartzman 2016). Another step in automating political participation can be seen in apps such as Congress, iCitizen, and Countable in the United States and RepresentMe in the United Kingdom, which flag legislation 
of interest and automate sending opinions about legislation to elected representatives. In 2016, an AI chatbot successfully contested and overturned 160,000 parking tickets in London and New York (Gibbs 2016).

Software can also facilitate democracy by making it easier to use weighted voting methods, such as rank order preference ballots or the upranking of votes in Reddit, and decision making through plebiscites or the aggregation of public opinion (Frey 2016), ideas being tested in platforms such as the Condorcet Internet Voting Service, Civitas, loomio.org, democracyos.org, and liquidfeedback.org (Sandberg 2014).

\section{Cognitively Enhanced and Neurally Networked Citizens}

Although we can never know enough to make completely informed decisions as citizens, or have the time to participate in all the issues that impact our lives, we can all know more and do more. Literacy and the printing press, and then universal public education, allowed ordinary people wider access to knowledge, which in turn enabled the spread of suffrage and democratic accountability. Today hacktivism and the Net have accelerated the amount of knowledge we can accumulate and the rapidity with which we can organize, but citizen activism still relies on our flawed and constrained neurology. Soon, however, brains will be connected directly to machines with expanded capacity for memory and information processing, enabling both more empowered elites, corporations, and governments and more empowered citizens. In a future of algorithmic governance, only cyborg citizens will be able to keep up with the speed and complexity of power (Danaher 2014, 2016).

In "Utopias and Dystopias as Cybernetic Information Systems," Matthew Gladden (2015) reflects on the possibility of utopian "posthuman neuropolities," democracies enabled by brainmachine interfaces. In these future utopias, information would be aggregated from all its "nodes" 
to serve social needs and maintain social homeostasis, as it is among the Conjoiners and Demarchists in Alastair Reynolds' science fiction. Reynolds' Conjoiners and Demarchists have brain-machine devices that allow them to maintain unique individual personalities simultaneously with group-level consciousness and constant subconscious opinion aggregation and decision making. The same technologies could also enable dystopian neuropolities such as the Matrix and the Borg in Star Trek. In these dystopian scenarios, the machinery of governance subordinates individual subjectivity to the interests of the machine.

\section{Final Thoughts}

The state is withering, as bureaucracy is translated into algorithms and the public sector is automated. Like bureaucracies, these algorithms need transparency, robust democratic oversight and citizen engagement to ensure that they are fair and serve the interests of the many and not the few. As artificial intelligence grows in power, it is also being enlisted in governance and can be used to strengthen democratic oversight and citizen participation in governance, or to create dystopian top-down systems of totalitarian control, or out-of-control all-powerful, self-interested machine minds. In our ideal future, democratically accountable governance algorithms, first in apps and then connected to brains, could unite citizens, informed by bottom-up sousveillance data, and organized with democracy software. As technological unemployment shrinks the amount of paid work, and we establish a universal basic income guarantee, the algorithmic state can be increasingly in charge of equitably distributing postcapitalist abundance, replacing market mechanisms with democratic planning. Indeed, as we face threats posed by accelerating technological innovation, from climate change and bioterrorism to emergent self-willed artificial intelligence, only an algorithmically enhanced democracy can secure our future. 
James Hughes, Ph.D., is the Executive Director of the Institute for Ethics and Emerging Technologies. A bioethicist and sociologist, Dr. Hughes serves as Associate Provost for the University of Massachusetts Boston. He holds a doctorate in sociology from the University of Chicago and is author of Citizen Cyborg: Why Democratic Societies Must Respond to the Redesigned Human of the Future.

\section{Work Cited}

Abdukadirov, Sherzod, ed. 2016. Nudge Theory in Action: Behavioral Design in Policy and Markets. Basingstoke, UK: Palgrave MacMillan.

Akin, William E. 1977. Technocracy and the American Dream: The Technocrat Movement, 1900-1941. Berkeley, CA: University of California Press.

Aletras, Nikoloas, Dimitrios Tsarapatsanis, Daniel Preoţiuc-Pietro, and Vasileios Lampos. 2016. "Predicting Judicial Decisions of the European Court of Human Rights: A Natural Language Processing Perspective.” PeerJ Computer Science, https://doi.org/10.7717/peerjcs.93; accessed 9 August 2017.

Anissimov, Michael. 2007. Objections to Coherent Extrapolated Volition. Singularity Institute for Artificial Intelligence.

Arkin, Ron. 2009a. "Ethical Robots in Warfare." IEEE Technology and Society Magazine 28 (1): $30-33$.

Arkin, Ron. 2009b. Governing Lethal Behavior in Autonomous Robots. Boca Raton, FL: Taylor and Francis. 
Atherton, Kelsey D. 2014. "Robots May Replace One-Fourth Of U.S. Combat Soldiers By 2030, Says General," Popular Science Jan 22. https://www.popsci.com/article/technology/robotsmay-replace-one-fourth-us-combat-soldiers-2030-says-general; accessed 9 August 2017.

Bader, Michael. 2016. "Reign of the Algorithms: How "Artificial Intelligence" Is Threatening Our Freedom.” Herrschaft der Algorithmen 8 (22). https://www.gfe-media.de/blog/wpcontent/uploads/2016/05/Herrschaft_der_Algorithmen_V08_22_06_16_EN-mb04.pdf; accessed 9 August 2017.

Baker, Kevin. 2011. Red Helmsman: Cybernetics, Economics, and Philosophy in the German Democratic Republic. Georgia State University Master's Thesis.

Bartlett, Steven James. 2016. The Case for Government by Artificial Intelligence. http://www.willamette.edu/ sbartlet/Documents/Bartlett_The\%20Case\%20for\%20Govern ment\%20by\%20Artificial\%20Intelligence.pdf; accessed 9 August 2017.

BBC. 2016. "Kenyan App Ushahidi Monitoring US Elections." BBC, November 8. http://www.bbc.com/news/world-africa-37910068; accessed 9 August 2017.

Beer, Stafford. 1959. Cybernetics and Management. London, UK: English Universities Press.

Beer, Stafford. 1972. "The Liberty Machine," Cybernetics, Artificial Intelligence, and Ecology,

Herbert W. Robinson and Douglas E. Knight eds., 9-25. American Society for Cybernetics.

Bellamy, Edward. 1888. Looking Backward. New York, NY: Magnum.

Bostrom, Nick. 2001. "Analyzing Human Extinction Scenarios and Related Hazards.” Journal of Evolution and Technology 9 (1). 
Bostrom, Nick. 2006. "What Is a Singleton?" Linguistic and Philosophical Investigations 5 (2): $48-54$.

Bostrom, Nick. 2014. Superintelligence. Oxford, UK: Oxford University Press.

Botsman, Rachel. 2017. "Big data meets Big Brother as China moves to rate its citizens," Wired UK Oct 21. https://www.wired.co.uk/article/chinese-government-social-credit-scoreprivacy-invasion; accessed 9 August 2017.

Brideshead, Sue. 2017. "Could Technology Remove the Politicians from Politics?"

Motherboard, January 3. https://motherboard.vice.com/en_us/article/wnxbyb/democracyby-app; accessed 9 August 2017.

Browning, Lynnley. 2015. "IRS Using Artificial Intelligence to Sniff for Tax Dodgers." Columbus Dispatch, October 19. http://www.dispatch.com/article/20151018/news/310189877; accessed 9 August 2017.

Buckley, Walter F.. 1967. Sociology and Modern Systems Theory. NY, NY: Prentice Hall.

Burns, Tom R., and Helena Flam. 1987. The Shaping of Social Organization-Social Rule System Theory with Applications. London: Sage.

Carson, Kevin. 2011 “Taylorism, Progressivism, and Rule by Experts.” Foundation for Economic Education. https://fee.org/articles/taylorism-progressivism-and-rule-by-experts/ Chin, Josh, and Liza Lin. 2017. “China’s All-Seeing Surveillance State Is Reading Its Citizens' Faces.” Wall Street Journal. June 26.

Chin, Josh, and Gillian Wong. 2016. “China's New Tool for Social Control: A Credit Rating for Everything," Wall Street Journal, November 28.

Citizen's Foundation. 2016. “Active Citizen.” http://www.citizens.is/active/; accessed 9 August 2017. 
Cochrane, James, and John Graham. 1976. "Cybernetics and Macroeconomics.” Economic Inquiry 14 (2): 241-50.

Cockshott, W. Paul, and Allin Cottrell. 1993. Towards a New Socialism. Nottingham, UK: Spokesman.

Cottrell, Allin, and W. Paul Cockshott. 2007. "Against Hayek." MPRA Paper 6062. Munich, Germany: University Library.

D-CENT. 2016. A New Co-Designed Model for Citizen Participation in Helsinki. https://dcentproject.eu/a-new-co-designed-model-for-citizen-participation-in-helsinki/; accessed 9 August 2017.

Danaher, John. 2014. "Rule by Algorithm? Big Data and the Threat of Algocracy." Ethical Technology. January 7. http://ieet.org/index.php/IEET/more/danaher20140107; accessed 9 August 2017.

Danaher, John. 2016. "The Threat of Algocracy: Reality, Resistance and Accommodation." Philosophy and Technology (January 2016): 1-24.

Davis, Joshua. 2017. “Hear Me Out: Let’s Elect a Robot President.” Wired, May 18. https://www.wired.com/2017/05/hearletselectaipresident/; accessed 9 August 2017.

Deutsch, Karl W. 1963. The Nerves of Government: Models of Political Communication and Control. New York, NY: The Free Press of Glencoe.

Dunleavy, Patrick, and Leandro Carrera. 2013. Growing the Productivity of Government Services. Edward Elgar.

Eggers, William, and David Schatsky. 2017. AI-Augmented Government: Using Cognitive Technologies to Redesign Public Sector Work. NY, NY: Deloitte University Press. 
Elkus, David. 2015. “You Can’t Handle the (Algorithmic) Truth: People Are Blaming Algorithms for the Cruelty of Bureaucracy." Slate, May 20. http://www.slate.com/articles/technology/future_tense/2015/05/algorithms_aren_t_responsi ble_for_the_cruelties_of_bureaucracy.html; accessed 9 August 2017.

Engels, Frederick. 1878/1947. Anti-Dühring. Herr Eugen Dühring’s Revolution in Science. Moscow: Progress Publishers.

Fresco, Jacques. 1995. The Venus Project: The Redesign of Culture. Venus, FL: Global CyberVisions.

Frey, Thomas. 2016. “Will Artificial Intelligence Improve Democracy or Destroy It?” DaVinci Institute. http://www.futuristspeaker.com/business-trends/will-artificial-intelligenceimprove-democracy-or-destroy-it/; accessed 9 August 2017.

Furness, Dylan. 2016. “An AI Cybersecurity System May Detect Attacks with 85 Percent Accuracy." TechEmergence.com. April 23.

Gerovitch, Slava. 2001. "Russian Scandals: Soviet Readings of American Cybernetics in the Early Years of the Cold War.” Russian Review 60: 545-68.

Gerovitch, Slava. 2002. From Newspeak to Cyberspeak: A History of Soviet Cybernetics. Cambridge, MA: MIT Press.

Gibbs, Samuel. 2016. "Chatbot Lawyer Overturns 160,000 Parking Tickets in London and New York.” Guardian, June 28. https://www.theguardian.com/technology/2016/jun/28/chatbotai-lawyer-donotpay-parking-tickets-london-new-york; accessed 9 August 2017.

Gladden, Mathew. 2015. "Utopias and Dystopias as Cybernetic Information Systems: Envisioning the Posthuman Neuropolity." Creatio Fantastica 2015-3 (50): 1-25. 
Graeber, David. 2015. The Utopia of Rules: On Technology, Stupidity, and the Secret Joys of Bureaucracy. Brooklyn, NY Melville House.

Hayek, Frederick. 1944. The Road to Serfdom. Chicago, IL: University of Chicago Press.

Helbing, Dirk, Bruno S. Frey, Gerd Gigerenzer, Ernst Hafen, Michael Hagner, Yvonne Hofstetter, Jeroen van den Hoven, Roberto V. Zicari, and Andrej Zwitter. 2017. "Will Democracy Survive Big Data and Artificial Intelligence?” Scientific American. https://www.scientificamerican.com/article/will-democracy-survive-big-data-and-artificialintelligence/; accessed 9 August 2017.

Howard, Alexander. 2015. "This Startup Is Like Google For Congress, And Legislators Love It," HuffingtonPost.com. Oct 27.

Howard, Ayanna and Jason Borenstein. 2017. "The Ugly Truth About Ourselves and Our Robot Creations: The Problem of Bias and Social Inequity," Science and Engineering Ethics 23(6): 1-16. Doi: 10.1007/s11948-017-9975-2

Joseph, Peter. 2017. The New Human Rights Movement: Reinventing the Economy to End Oppression. NY, NY: Ben Bella Books.

Kuncel, Nathan R., David Klieger, Brian Connelly, and Deniz Ones. 2013. "Mechanical versus Clinical Data Combination in Selection and Admissions Decisions: A Meta-analysis," Journal of Applied Psychology 98 (6): 1060-72.

Lam, Bourree. 2015. "For More Workplace Diversity, Should Algorithms Make Hiring Decisions?" The Atlantic, June 22. https://www.theatlantic.com/business/archive/2015/06/algorithm-hiring-diversityHR/396374/; accessed 9 August 2017. 
Larson, Jeff, Surya Mattu, Lauren Kirchner, and Julia Angwin. 2016. "How We Analyzed the COMPAS Recidivism Algorithm.” ProPublica, May 23.

https://www.propublica.org/article/how-we-analyzed-the-compas-recidivism-algorithm; accessed 9 August 2017.

Leijonhufvud, Axel. 1972. On Keynesian Economics and the Economics of Keynes: A Study in Monetary Theory. Oxford, UK: Oxford University Press.

Letouzé, Emmanuel, and David Sangokoya. 2015. Leveraging Algorithms for Positive Disruption: On Data, Democracy, Society and Statistics. Cambridge, MA: Data Pop Alliance.

Levy, David M., and Sandra J. Peart. 2008. "Socialist Calculation Debate." In The New Palgrave Dictionary of Economics, 2nd ed., ed. Steven N. Durlauf and Lawrence E. Blume. Basingstoke, United Kingdom: Palgrave Macmillan. http://www.dictionaryofeconomics.com/article?id=pde2008_S000535; accessed 9 August 2017.

Linhorst, Michael. 2017. “Could a Robot Be President?” Politico, July 8. http://www.politico.com/magazine/story/2017/07/08/robot-president-215342; accessed 9 August 2017.

Lu, Clara. 2014. “Incredibly Successful Supply Chain Management: How Does Walmart Do It?” TradeGecko. https://www.tradegecko.com/blog/incredibly-successful-supply-chainmanagement-walmart; accessed 9 August 2017.

MacArthur Foundation. 2017. Opening Governance: The Context. http://www.openinggovernance.org; accessed 9 August 2017. 
McClelland, Kent A., and Thomas J. Fararo, eds. 2006. Purpose, Meaning, and Action: Control Systems Theories in Sociology. Basingstoke, United Kingdom: Palgrave Macmillan.

Medina, Eden. 2011. Cybernetic Revolutionaries: Technology and Politics in Allende's Chile. Cambridge, MA: The MIT Press.

Medina, Eden. 2015. "Rethinking Algorithmic Regulation,” Kybernetes 44 (6):1005-19.

Morozov, Evgeny. 2013a. “The Real Privacy Problem.” MIT Technology Review, Oct 22. https://www.technologyreview.com/s/520426/the-real-privacy-problem/; accessed 9 August 2017.

Morozov, Evgeny. 2013b. To Save Everything, Click Here: The Folly of Technological Solutionism. New York, NY: PublicAffairs/Perseus Books.

Muri, Allison. 2007. The Enlightenment Cyborg. A History of Communications and Control in the Human Machine 1660-1830. Toronto, Canada: University of Toronto Press.

Nay, John. 2017. "Predicting and Understanding Law-Making with Word Vectors and an Ensemble Model.” PLoS ONE 12 (5): e0176999.

Nove, Alec. 1983. The Economics of Feasible Socialism. Abingdon, UK: Routledge.

O'Neil, Cathy. 2016. Weapons of Math Destruction: How Big Data Increases Inequality and Threatens Democracy. New York, NY: Broadway Books.

Outram, Dorinda. 2005. The Enlightenment, 2nd ed. Cambridge, UK: Cambridge University Press.

Parsons, Talcott. 1960. Structure and Process in Modern Societies. NY, NY: Free Press. Pomerleau, Mark. 2017. “Is Technology a Threat to Human Intelligence?” C4isrnet.com, July 25. http://www.c4isrnet.com/intel-geoint/2017/08/25/is-technology-a-threat-to-humanintelligence accessed July 15, 2017. 
Prine, Carl. 2017. "Robots Poised to Take Over Wide Range of Military Jobs.” San Diego Union Tribune, Feb 2.

http://www.sandiegouniontribune.com/military/sdmerobotsmilitary20170130story.html; accessed July 15, 2017.

Pruchnic, Jeff. 2014. Rhetoric and Ethics in the Cybernetic Age: The Transhuman Condition. Abingdon, UK: Routledge.

Raymond, Allen. 1933. What Is Technocracy? New York, NY: McGraw-Hill.

Rindzeviciute, Egle. 2010. "Purification and Hybridisation of Soviet Cybernetics: The Politics of Scientific Governance in an Authoritarian Regime.” Archiv für Sozialgeschichte 50: 289309.

Ross, Eleanor. 2016. “Apps for Democracy_Open Data and the Future of Politics.” Guardian, August 19. https://www.theguardian.com/media-network/2016/aug/19/apps-fordemocracy-open-data-and-the-future-of-politics; accessed July 15, 2017.

Sandberg, Anders. 2014. “Smarter Policymaking through Improved Collective Cognition?” In Anticipating 2025: A Guide to the Radical Scenarios That Lie Ahead, Whether or Not We're Ready for Them, ed. David Wood, 1-17. London: London Futurists.

Seetharaman, Deepa. 2016. "Facebook Eyes Artificial Intelligence for Spotting Fake News." Wall Street Journal, December 1. https://www.wsj.com/articles/facebook-could-developartificial-intelligence-to-weed-out-fake-news-1480608004; accessed July 15, 2017.

Shapiro, Isaac. 2017. Federal Employment at Record Lows as a Share of Employment, Population-Yet Trump May Freeze Hiring. Center for Budget and Policy Priorities, January 12. 
Smith, Thomas. 2016. "Oracles, Genies and Sovereigns: Artificial Intelligence and Artificial Government." The Criterion Journal on Innovation 1: 1-48. https://papers.ssrn.com/sol3/papers.cfm?abstract_id=2637707; accessed July 15, 2017.

Sochor, Zenovia. 1988. Revolution and Culture: The Bogdanov-Lenin Controversy. Ithaca, NY: Cornell University Press.

Sotala, Kaj. 2007. 14 objections against AI/Friendly AI/The Singularity answered. http://kajsotala.fi/2007/10/14-objections-against-aifriendly-aithe-singularity-answered; accessed 9 August 2017.

Steiner, Christopher. 2012. Automate This: How Algorithms Came to Rule Our World. New York, NY: Portfolio/Penguin.

Thaler, Richard H., and Cass R. Sunstein. 2008. Nudge: Improving Decisions About Health, Wealth, and Happiness. New Haven, CT: Yale University Press.

TZM Lecture Team. 2014. The Zeitgeist Movement Defined: Realizing a New Train of Thought. CreateSpace Independent Publishing Platform.

Umpleby, Stuart A. 2011. "Second-Order Economics as an Example of Second-Order Cybernetics." Cybernetics and Human Knowing 18 (3-4): 173-76.

UNRISD. 2004. Technocratic Policy Making and Democratic Accountability. http://www.unrisd.org/80256b3c005bccf9/(httpauxpages)/ae49cc52befc658ec1256efa002d 44fb/\$file/rpb3e.pdf; accessed 9 August 2017.

Viechnicki, Peter, and William D. Eggers. 2017. "How Much Time and Money Can AI Save Government?” Deloitte. https://dupress.deloitte.com/dup-us-en/focus/cognitivetechnologies/artificial-intelligence-government-analysis.html; accessed September 1, 2017. 
Von Mises, Ludwig. 1990 [1920]. Economic Calculation in the Socialist Commonwealth. Auburn, AL: Mises Institute. Originally "Die Wirtschaftsrechnung im sozialistischen Gemeinwesen.” Archiv für Sozialwissenschaften 47 (1920).

Wartzman, Rick. 2016. “American Workers Try to Organize-One Click at a Time.” Fortune, February 16. http://fortune.com/2016/02/16/workers-group-our-walmart-use-tech-toorganize/; accessed 9 August 2017.

Watney, Caleb. 2017. "It's Time for Our Justice System to Embrace Artificial Intelligence.” Washington, DC: Brookings Institution. https://www.brookings.edu/blog/techtank/2017/07/20/its-time-for-our-justice-system-toembrace-artificial-intelligence; accessed 9 August 2017.

Wiener, Norbert. 1956. The Human Use of Human Beings-Cybernetics and Society. Garden City, NY: Doubleday.

Wiener, Norbert. 1961. Cybernetics: Or Control and Communication in the Animal and the Machine. Cambridge, MA: MIT Press.

Woolley, Samuel C., and Douglas Guilbeault. 2017. "Computational Propaganda in the United States of America: Manufacturing Consensus Online.” Oxford, UK: Project on Computational Propaganda.

World Bank. 2017. World Development Indicators. http://wdi.worldbank.org; accessed 9 August 2017.Yeung, Karen. 2017. “'Hypernudge': Big Data as a Mode of Regulation by Ddesign.” Information, Communication and Society 20 (1):118-36.

Yudkowsky, Eliezer. 2004. Coherent Extrapolated Volition. Machine Intelligence Research Institute. 
Yudkowsky, Eliezer. 2008. "Artificial Intelligence as a Positive and Negative Factor in Global Risk," In Global Catastrophic Risks, edited by Nick Bostrom and Milan M. Ćirković, 308345. New York: Oxford University Press. 